\title{
Gene Therapy in India- Current Status
}

\author{
Neha Thakur ${ }^{1}$ Prerna Batra', Kuldeep Singh ${ }^{3}$, Piyush Gupta ${ }^{2}$ \\ Department of Pediatrics, Hind Institute of Medical Sciences ${ }^{1}$, \\ University College of Medical Sciences and Guru Tegh Bahadur Hospital'², \\ AIIMS, Jodhpur'.
}

\begin{abstract}
Gene therapy is being considered as a promising modality for more than two decades now. It has been used for a number of difficult-to-treat conditions and has shown good results in some of the conditions, but not that effective in some others. Overcoming the initially faced hindrances, the research in the field of gene therapy resurged. India is one the major Asian countries where gene therapy-related research and centers have shown remarkable growth, despite certain constraints faced by the researchers. Current article discusses the different types of gene therapy along with its clinical implications and its current status in Indian context.
\end{abstract}

Keywords: Gene therapy, India, children.

\section{Introduction}

Gene therapy is an attempt to treat diseases by replacing defective gene with healthy genes or repairing the defective genes in order to improve the function of genes. World was first introduced to gene therapy in 1995 almost two decades ago when Blaese et al published his initial trial results of T lymphocyte directed gene therapy in Adenosine Deaminase (ADA) deficiency associated Severe Combined Immunodeficiency (SCID) (1).

Hindrances to gene therapy started following three deaths which occurred just after clinical initiation of gene therapy. One was due to multiple organ failure as a consequence of severe immune response to the viral vector and other two children died of leukemia $(2,3)$. These deaths raised issues of ethical concern following gene therapy and lead to complete halt of the trials all over the world. After the initial set back, interest later renewed almost a decade later in the year 2008, when gene therapy restored vision in three young children suffering from Leber's congenital amaurosis (4). After these successful results of gene therapy, United States of America and Europe became the pioneers in gene therapy-related studies and clinical trials. In Asian continent, China and Japan have emerged as the forerunners in the stem cell research, with China launching Gendicine, an injectable gene therapy product (a replicationincompetent recombinant human p53 wild type protein particles combined with adenovirus serotype 5) approved by the China Food and Drug Administration (CFDA) in 2003 for head and neck cancer. Japan has introduced Retronectin reagent, which is a recombinant human Fibronectin Fragment and on injection, enhances retroviral (as well as lentivirus, a form of retrovirus)-mediated gene transfection and transduction by helping the co-localization of target cell and virions. The reagent can enhance

Correspondence: Prof. Prerna Batra, Professor of Pediatrics, University College of Medical Sciences and Guru Tegh Bahadur Hospital, Dilshad Garden, Delhi-110095, India. Mob: 9958672759. Email: drprernabatra@yahoo.com. 
retroviral-mediated gene transfer to target cells that express integrin receptors VLA-4 and/or VLA-5, thus making the gene delivery more specific as the gene will not be delivered to body cells which lack VLA-4 and/or VLA-5 integrin receptors.

\section{Types of Gene Therapy}

It becomes important to understand some of the terminologies and the types that are often used in relation to gene therapy. Alternative terms like genetic engineering, Deoxyribonucleic Acid (DNA)-based therapy and molecular therapy are often used by layman and biologists. Gene therapy is one of the tool of genetic engineering used with purpose to alleviate suffering from hereditary diseases. However, genetic engineering in wider term not only aims to alter genes to correct genetic defects but may also be involved in modifying the genes to enhance the capabilities of the organism beyond what is normal. The latter is a dangerous proposition of genetic engineering.

A. Gene therapy can be classified into somatic cell and germ cell types, depending upon the type of cells that are modified by the therapeutic genes $(6,7)$. All the gene therapies till date are directed towards somatic cells only.

\section{Somatic Cell Gene Therapy}

In this type, genetic changes are directed towards somatic cells. As these cells are nonreproductive, effect is not passed into future generations, making it safer. The disadvantage is short duration of effects of somatic cell therapy as most tissues will be replaced by new tissues.

\section{Germ Cell Gene Therapy}

This is the type of gene therapy, where germ cells, i.e. either sperm or ova are introduced with therapeutic gene, leading to the changes that are inheritable, i.e. changes in gene may affect future generations.
B. Based upon the technique of delivery of vectors to the target cell, gene therapy can be further classified into ex-vivo and in-vivo therapy.

\section{Ex-vivo Gene Therapy}

Ex-vivo gene therapy is where the defected cells are extracted out of the body and targeted with therapeutic gene. Once successfully modified, they are cultured ex-vivo and transferred back to the host, where now the corrected gene replicates.

\section{In-vivo Gene Therapy}

In this modality, a vector that is capable of carrying the therapeutic gene, is used to inject host cells with normal gene.

C. The type of change brought out in the faulty gene classifies gene therapy as either gene replacement or gene addition.

\section{Gene Replacement}

Gene replacement means replacement of defective gene with a corrected one.

\section{Gene Addition Therapy}

Gene addition means restoration of normal function of cell by addition of normal or functional copy of gene into genome. This concept is primarily used in various gene therapy related research on cancer.

\section{Clinical Implications}

\section{Cancer}

Gene therapy-related research and its clinical application have been mostly utilized in the field of malignancy. By the end of 2009, nearly two third of gene therapy-related research was concentrated on cancers (8). Oncolytic viruses are used to introduce genes into malignant cells, thereby causing death of 
malignant cells. Another approach is to deliver p53 gene (tumor suppressor gene) and thereby induce oncolysis. Gendicine that was first approved anticancer drug which was based on this gene therapy principle. Suicide gene therapy is another attempt to treat tumor by delivering of gene coding for enzyme that metabolizes prodrugs into locally active chemotherapeutic drug moiety.

\section{Single Gene Disorder}

Gene therapy has a significant role in the treatment of single gene disorders like muscular dystrophies, cystic fibrosis, alpha-1-antitrypsin deficiency, Huntington's disease, lysosomal storage diseases, chronic granulomatous disease, ornithine transcarbamylase deficiency, junctional epidermolysis bullosa, haemophilia, etc. (8).

\section{Immunodeficiency}

Over the years with development of gene therapy first major progression has been seen since the first trial in early nineties. After the initial set back where two patients treated for Xlinked severe combined immunodeficiency (XSCID) using retroviral vectors died with leukemia there were clinical trials that had showed clear therapeutic benefits of gene therapy in treatment of both X-SCID and SCID caused by adenosine deaminase (ADA) deficiency. Besides primary immunodeficiency, secondary immunodeficiency states like Human Immunodeficiency Virus (HIV) infection has also evolved as potential candidate for gene therapy. Transgenes can be transferred into haematopoietic stem cells or into T-cells, for specific protection against HIV infection to these cells. They act by disabling HIV-1 protein, or making the milieu unsuitable for HIV-1 replication (8).

\section{Eye Diseases}

It was for Leber's congenital amaurosis that there was renewal of faith in gene therapy after the initial set back seen in SCID. Eye being a small organ, hence it is possible that we can transfect a large number of ocular cells. Potential ophthalmologic conditions for gene therapy are glaucoma, Leber's hereditary optic neuropathy, red-green colour blindness and macular degeneration (9). A phase I study is going on to show effects of antiangiogenic cytokine Pigment Epithelium-derived Factor (PEDF) in treating age-related macular degeneration (9). Mancuso et al has also shown significant improvement in producing trichromatic colour vision in adult redgreen colour blind monkeys by subretinal injection of adeno-associated virus containing a L-opsin gene (10).

\section{Cardiac Diseases}

Cardiac diseases are multigenic in origin, hence difficult to treat. There have been trials where scientists have devised techniques to deliver genes for various growth factors like vascular endothelial growth factors (VEGF), Fibroblast Growth Factors (FGF) to promote vascular angiogenesis (11). Though their results did not show significant improvement in stressinduced myocardial perfusion but improved regional wall motion indicated a favorable antiischemic effect encouraging further research in the field.

\section{Central Nervous System (CNS) Disorders}

Unlike cardiac, in neurological disorders gene therapy has shown promising results to treat Parkinsonism (12) and Alzheimer's disease (13). There have been several trials on gene therapy in Parkinsonism which are still in phase 1 and phase 2 but are showing gene therapy to be safe, tolerable and potential candidate for invivo studies (12). Various approaches used are, transmitting the gene for glutamic acid decarboxylase into the subthalamic nucleus (12) or delivery of the gene for neurturin in putamen cell bodies (14). Similarly in Alzheimer's disease gene therapy is being attempted to deliver Nerve Growth Factor gene into the human CNS (13). 


\section{Intrauterine Gene Therapy}

Prenatal gene therapy or otherwise known as intrauterine gene therapy to resolve the problems of various genetically transmitted diseases is the future of gene therapy. If successful, we can diagnose and treat certain genetic disorders before they manifest in a child. Animal studies have shown some success in the field(15).

\section{Difficulties with Somatic Cell Gene Therapy}

Multiple rounds of gene therapy are required due to its short lived nature depending upon the turn-over rate of cells replication. The rapidly dividing nature of many cells prevent the gene therapy from achieving long-term benefits. The therapeutic DNA that is introduced into the target cells must remain functional and stable for long duration. Gene therapy is particularly effective in single gene disorders, hence difficult to apply in multigenic disorders. However, Thalassemia and haemoglobinopathies, though amenable to gene therapy present technical challenges in gene regulation.

The other problem faced is with the mode and the type of vectors used for the gene delivery. Initially viral vectors were used to deliver gene but the problems of endogenous virus recombination, oncogenic effects and most importantly unexpected immune response as seen in the very first case of gene therapy remain the concerns (2).

\section{Ongoing Research in the Field of Gene Therapy}

\section{Introduction of New Vectors}

Various non-viral vectors that are presently being given consideration for gene therapy are naked DNA, oligonucleotides, lipoplexes and polyplexes dendrimers, etc. The advantages these vectors hold over viral vectors is low immunogenicity, rapid turnover and low toxicity. Most of these vectors are still in experimental stage and we are far from development of a perfect vector of gene therapy. Non-viral vectors can further be classified into those limited to in-vitro applications like calcium phosphate transfection which is the system of choice for transmitting plasmid DNA into variety of cell cultures. Another type of nonviral vectors are also there which have both invivo and in-vitro applications like cationic liposomes, etc.

\section{Gene Therapy in India}

In India though interest in gene therapy took some time but with financial assistance provided by different government agencies, the country has shown rapid improvement in gene therapy-related research placing India third among the major Asian countries having gene therapy laboratories (16). The main aim is to develop new institutions for gene therapy research, strengthening of existing institutions which have good expertise in this area in order to initiate work in molecular genetics for decreasing the burden of genetic disorders in the country. The pioneer of gene therapy-related research in India is Advanced Centre for Treatment, Research and Education for Cancer (ACTREC) where active work on gene therapy for head and neck cancer using synthetic vectors is being carried out (17). It is heartening to note that scientists in over dozen of labs in India are working hard with small steps in contributing towards gene therapy work as depicted in Table 1 (18-24). Hareendran et al (18) suggested that targeting specific host cellular proteins is helpful to attenuate the immune barriers which are a key obstacle in clinical application of adenoassociated virus mediated gene therapy. An alternate approach for treating Haemophilia; a using allogenic transplantation in liver where tolerance against donor antigens can be induced by in-vitro allo-antigen primed T-regulatory (Treg) cells has been studied by Kochat and her team. Shetty et al (19) have shown that naïve stemness of pluripotent cells can be generated by devising a transgenic method to express a human ortholog of protein Asrij, present on mouse 
Table I: Indian Scientists work on Gene Therapy

\begin{tabular}{|c|c|c|c|}
\hline Investigators & Study & Year (ref) & State \\
\hline Kochat et al & $\begin{array}{l}\text { Repression of PARP-1, a DNA damage response protein, } \\
\text { improves the transduction of single-stranded AAV vectors both } \\
\text { in vitro and in vivo in mice. Findings will help Hemophilia B } \\
\text { patents. }\end{array}$ & $2016(18)$ & Tamil Nadu \\
\hline $\begin{array}{l}\text { Hareendran et } \\
\text { al }\end{array}$ & $\begin{array}{l}\text { Examined the role of donor major histocompatibility complex } \\
(\mathrm{MHC}) \text {-stimulated host CD4(+)CD25(+) regulatory T (Treg) } \\
\text { cells in suppressing immune responses against allogeneic } \\
\text { uncommitted (Lin(-)) bone marrow cells (BMCs) for correction } \\
\text { of bleeding disorder in HA mice. }\end{array}$ & $2015(17)$ & Delhi \\
\hline $\begin{array}{l}\text { Shetty and } \\
\text { Inamdar }\end{array}$ & $\begin{array}{l}\text { Ectopically expressed Asrij in epiblast stage equivalent-human } \\
\text { embryonic stem cells (hESCs) to test for induction of naive } \\
\text { pluripotency in primed pluripotent cells. The construct pCAG- } \\
\text { Asrij was introduced into hESCs by microporation. Ectopic } \\
\text { expression of Asrij in BJNhem } 20 \text { hESC line was performed by } \\
\text { selecting for plasmid transfection, followed by stable cell line } \\
\text { generation. }\end{array}$ & \begin{tabular}{|l|}
$2016(19)$ \\
\end{tabular} & Bangalore \\
\hline Misra et al & $\begin{array}{l}\text { Liposomal transfection mediated gene transfer for tumors } \\
\text { expressing Sigma receptors. }\end{array}$ & $2016(20)$ & Bangalore \\
\hline Vij et al & $\begin{array}{l}\text { They reported an amphipathic peptide Mgpe9 that can penetrate } \\
\text { the uncompromised skin, enter skin cells and deliver plasmid } \\
\text { DNA efficiently as nano-complexes in vitro and in vivo without } \\
\text { any additional physical or chemical interventions prevalent } \\
\text { currently leading to efficient gene expression up to the highly } \\
\text { proliferating basal layer of the skin without observable adverse } \\
\text { reactions or toxic effects. }\end{array}$ & $2016(21)$ & Delhi \\
\hline $\begin{array}{l}\text { Hati Boruah } \\
\text { et al }\end{array}$ & $\begin{array}{l}\text { Knockdown of myostatin gene (MSTN), transforming growth } \\
\text { factor- } \beta \text { superfamily, and a negative regulator of the skeletal } \\
\text { muscle growth, by RNA interference (RNAi), has been reported } \\
\text { to increase muscle mass in mammals. This could provide an } \\
\text { alternative strategy of gene knockout and develop stable } \\
\text { caprinefetal fibroblast cells. Furthermore, these stable cells can } \\
\text { be used as a cell donor for the development of transgenic cloned } \\
\text { embryos by somatic cell nuclear transfer (SCNT) technique. }\end{array}$ & $2016(22)$ & $\begin{array}{l}\text { Madhya } \\
\text { Pradesh }\end{array}$ \\
\hline Kumar et al & $\begin{array}{l}\text { siRNA could be used in cancer therapy if naked nucleic acid } \\
\text { could be transported using a suitable carrier. The authors } \\
\text { developed a nano-carrier system using } \\
\text { mesoporouspolycaprolactone (hmPCL) and showed its efficacy } \\
\text { in knocking down cancer cells. This approach may open } \\
\text { another way of gene therapy. }\end{array}$ & $2016(23)$ & Telengana \\
\hline Sarkar et al & $\begin{array}{l}\text { A new Cancer Terminator Virus (CTV), Ad.tCCN1-CTV- } \\
\mathrm{m} 7 \text { was developed which displayed dose-dependent killing of } \\
\text { Carcinoma Prostate (CaP) without harming normal prostate } \\
\text { epithelial cells in vitro with significant anti-cancer activity in } \\
\text { vivo in both nude mouse CaPxenograft and transgenic Hi-Myc } \\
\text { mice (using ultrasound-targeted microbubble (MB)-destruction, } \\
\text { UTMD, with decorated MBs). }\end{array}$ & $2015(24)$ & Orissa \\
\hline
\end{tabular}


embryonic stem cells (mESCs) which is essential for maintaining pluripotency. Misra et al (20) are working on selective gene transfection as a possible strategy of interest for reducing off-target gene expression and toxicity. Vij et al (21) have used nucleic acid therapeutics as an effective topical delivery system to overcome the barrier posed by different layers of the skin in cutaneous disorders. Hati Boruah et al (22) showed Ribonucleic Acid interference (RNAi) based co-transfection method could provide an alternate route of gene knockout besides providing stable cells which can be used as a cell donor for the development of transgenic cloned embryos by somatic cell nuclear transfer technique. Alternative and efficient nucleic acid transportation has been demonstrated by Kumar et al (23). Sarkar et al (24) have studied therapeutic efficacy of combining a BH3 mimetic with a novel Cancer Terminator Virus for treating advanced carcinoma prostate.

\section{Obstacles in Growth of Gene Therapy in India}

After the initial work in late nineties, gene therapy remained at backseat for a long time as the government was uncertain whether to give priority to this technology. There is absence of the regulatory framework with inadequate exposure level of regulators who are still not updated with the international standards. Prohibitive cost involved in preparing reagents requiring cyclic guanosine monophosphate (cGMP) conditions is another major hurdle. As a result, researchers in India do not have the freedom to take risk in order to develop technology to save several lives. No established Indian guidelines are available on the preparation of clinical grade reagents for clinical trials. Centralized resources for production and distribution of clinical grade gene vectors are lacking. Laboratories or pharmaceutical companies catering to gene services are meager in number, further adding to the difficulties faced by the researchers. Most of gene therapy research is still lab based, preclinical and mostly limited to cancers.

\section{Road Ahead}

Despite the above road blocks, India is fast picking up with the rest of the world in developing research related to gene therapy. Adding impetus to further research in India is the release of revised "National Ethical Guidelines for Biomedical and Health Research Involving Human Participants, 2017" and the National Guidelines for Stem Cell Research, 2017 in October, 2017 by the Indian Council of Medical Research (ICMR). These guidelines would encourage research for somatic cell gene therapy for conditions for which it is the only therapeutic option available with due permission from Department of Biotechnology (DBT) for gene constructs (25).

Gene therapy has been theoretically very sound, but its utility will be demonstrated once it comes into clinical practice. Now with the "Make in India" being a popular mantra encouraged by the Govt. of India, we should not shy out from the active involvement in gene therapy research and trials. More funding for academic research, development of dedicated departments with scope for capacity building and training, integration between researchers and clinicians, increasing public awareness and finally and most importantly with the development of Indian guidelines for gene and cell therapy clinical research trials by the ICMR will help in the transition of gene therapy from infancy to adolescence.

\section{References}

1. Blaese RM, Culver KW, Miller AD, et al (1995). T lymphocyte-directed gene therapy for ADA-SCID: initial trial results after 4 years. Science 270:475-480.

2. Thrasher AJ, Gaspar HB, Baum C, et al (2006). Gene therapy: X-SCID transgene leukaemogenicity. Nature 443(7109): E5-E6.

3. Hacein-Bey-Abina S, Von Kalle C, Schmidt M, et al (2003). LMO2associated clonal $\mathrm{T}$ cell proliferation in 
two patients after gene therapy for SCIDX1. Science 302: 415-419.

4. Hauswirth WW, Aleman TS, Kaushal S, et al (2008). Treatment of leber congenital amaurosis due to RPE65 mutations by ocular subretinal injection of adenoassociated virus gene vector: short term results of a phase I trial. Hum Gene Ther 19: 979-990.

5. Niidome T, Huang L (2002). Gene therapy progress and prospects: nonviral vectors. Gene Ther 9: 1647-1652.

6. Gupta K, Singh S, Garg KN (2015). Gene therapy in dentistry: tool of genetic engineering. Revisited. Arch Oral Biol 60:439-446.

7. Patil PM, Chaudhari PD, Sahu M, Duragkar NJ (2012). Review article on gene therapy. Intl J Genet 4: 74-79.

8. TaniI J, Faustine B, Sufian JT (2011). Updates on current advances in gene therapy. West Ind Med J 60: 1-9.

9. Campochiaro PA, Nguyen QD, Shah SM, et al (2006). Adenoviral vector-delivered pigment epithelium-derived factor for neovascular-age-related macular degeneration: results of a phase I clinical trial. Hum Gene Ther 17:167-176.

10. Mancuso K, Hauswirth WW, Li Q, et al (2009). Gene therapy for red green colour blindness in adult primates. Nature 8:784787.

11. Kastrup J, Jorgensen E, Ruck A, et al (2005). Direct intra-myocardial plasmid vascular endothelial growth factor- A165 gene therapy in patients with stable severe angina pectoris A randomized doubleblind placebo controlled study: the Euroinject One trial. J Am Coll Cardiol 45:982-988.
12. Kaplitt MG, Feigin A, Tang C, et al (2007). Safety and tolerability of gene therapy with an adeno-associated virus (AAV) borne GAD gene for Parkinson's disease: an open label, phase I trial. Lancet 369:2097-2105.

13. Conner JM, Darracq MA, Roberts J, Tuszynski MH (2001). Nontropic actions of neurotrophins: subcortical nerve growth factor gene delivery reverses agerelated degeneration of primate cortical cholinergic innervation. Proc Natl Acad Sci USA 98:1941-1946.

14. Kordower JH, Herzog CD, Dass B, et al (2006). Delivery of neurturin by AAV2 (CERE-120)-mediated gene transfer provides structural and functional neuroprotection and neurorestoration in MPTP-treated monkeys. Ann Neurol 60:706-715.

15. Mattar $\mathrm{CN}$, Waddington $\mathrm{SN}$, Biswas A, et al (2012). The case for intrauterine gene therapy. Best Pract Res Clin Obstet Gynaecol 26:697-709.

16. Kim S, Peng Z, Kaneda Y (2008). Current status of gene therapy in Asia. Mol Ther 16 :237-243.

17. Kochat V, Kanjirakkuzhiyil S, Baligar P, Nagarajan P, Mukhopadhyay A (2015). Donor antigen-primed regulatory $\mathrm{T}$ cells permit liver regeneration and phenotype correction in hemophilia A mouse by allogeneic bone marrow stem cells. Stem Cell Res Ther 6:129.

18. Hareendran S, Ramakrishna B, Jayandharan GR (2016). Synergistic inhibition of PARP-1 and NF- $\kappa$ B signaling downregulates immune response against recombinant AAV2 vectors during hepatic gene therapy. Eur $J$ Immunol 46:154-166. 
19. Shetty DK, Inamdar MS (2016). Generation of a transgenic human embryonic stem cell line ectopically expressing the endosomal protein Asrij that regulates pluripotency in mouse embryonic stem cells: BJNhem20-Asrij. Stem Cell Res 16:331-333.

20. Misra SK, Moitra P, Kondaiah P, Bhattacharya S (2016). Co-liposomes having anisamide tagged lipid and cholesteryl tryptophan trigger enhanced gene transfection in sigma receptor positive cells. Colloids Surf B Biointerfaces 142:130-140.

21. Vij M, Natarajan P, Pattnaik BR, et al (2016). Non-invasive topical delivery of plasmid DNA to the skin using a peptide carrier. JControl Release 222:159-168.

22. Hati Boruah JL, Ranjan R, Gogoi H, et al (2016). Effect of co-transfection of anti- myostatin shRNA constructs in caprine fetal fibroblast cells. Anim Biotechnol 27:44-51.

23. Kumar VB, Medhi H, Yong Z, Paik P (2016). Designing idiosyncratic hmPCLsiRNA nanoformulated capsules for silencing and cancer therapy. Nanomedicine 12:579-588.

24. Sarkar S, Quinn BA, Shen XN, et al (2015). Therapy of prostate cancer using a novel cancer terminator virus and a small molecule $\mathrm{BH}-3$ mimetic. Oncotarget 6:10712-10727.

25. National Ethical Guidelines for Biomedical and Health Research involving Human Participants, 2017 and the National Guidelines for Stem Cell Research, 2017 . Available at http://icmr.nic.in/icmrnews/. Last Accessed 29.09.2016. 